\section{THE THEORY OF COMMUNICATIVE ACTION JÜRGEN HABERMAS}

Londres, Heinemann, Volumes I e II, 1984,465 e 457 páginas. Traduzido por Thomas McCarty.

Por Fernando C. Prestes Motta

Professor Titular do Departamento de Administração Geral e Recursos

Humanos da EAESP/ FGV.

$O^{t}$ ão três os objetivos fundamentais que Jürgen Habermas procura alcançar em Teoria da Ação Comunicatioa. Em primeiro lugar, busca desenvolver um conceito de racionalidade emancipado dos pressupostos subjetivistas e individualistas que têm perseguido a filosofia e as teorias sociais modernas. Em segundo lugar, busca desenvolver um conceito de sociedade em dois níveis, integrando os paradigmas de sistema e mundo de vida. Finalmente, busca elaborar uma teoria crítica da modernidade, trazendo à luz suas deficiências e patologias, com vistas a sugerir novas direções para o modernismo em vez de propugnar seu rechaço.

Para tanto, procede a uma reconstrução histórica das idéias dos teóricos sociais clássicos, passando por Max Weber, Durkheim, Mead, Marx, Lukacs, Horkheimer, Adorno e Parsons, tomados como parceiros num debate virtual. Desse modo, o filósofo busca pensar com eles, de forma a ultrapassá-los, através do confronto de suas idéias. Nesse enorme esforço, Habermas assume que uma teoria adequada da sociedade precisa integrar métodos e problemáticas anteriormente divididos entre a filosofia e a ciência social empírica.

Lembra, inicialmente, que o paradigma cartesiano do pensador solitário dominou o pensamento moderno desde o ínicio, como forma de pensar conhecimento e moralidade. Marcou o pensamento de Kant no final do século XVIII, não menos que seus predecessores empiricistas e racionalistas dos dois séculos anteriores. A subjetividade do paradigma cartesiano só será desafiada a partir do século XIX, com Hegel, ao demonstrar o caráter social e histórico das estruturas da consciência. Marx avança, ao afirmar que a mente não é a base da natureza e sim o inverso, descrevendo a consciência humana como contida, corporificada e prática. Para Marx, as formas de consciência constituem uma representação codificada das formas de reprodução social.

Também Darwin, ao estabelecer a continuidade das espécies humanas com relação ao resto da natureza, esboçou o caminho para o estabelecimento da relação entre inteligência e auto-preservação. Finalmente, Nietzsche e Freud mostraram o inconsciente no âmago da consciência, possibilitando a visualização do papel desempenhado pelo pré e não-conceitual no domínio do conceitual.

O resultado final, nas palavras de Jürgen Habermas, foi uma "dessublimação" do espírito e uma conseqüente desautorização da filosofia. Entretanto, as surpresas da história das idéias também ocorrem no século XX, e o paradigma cartesiano volta a influenciar consideralvelmente a filosofia, para, a seguir, receber novos influxos críticos, configurando um claro declínio do chamado paradigma da consciência. É a esse declínio que Habermas responde com uma mudança explícita para o paradigma da linguagem e com a conseqüente construção da teoria da ação comunicativa, partindo da constatação de que a reprodução das espécies humanas requer satisfação das condições de uma racionalidade inerente à ação comunicativa, visto que as atividades socialmente coordenadas dos homens se estabelecem e se mantêm através da comunicação.

No entanto, o atomismo caracteriza a maior parte do pensamento moderno. Nele, o sujeito coloca-se em oposição a uma infinidade de objetos, com ós quais mantém dois tipos básicos de relações: representação e ação. A racionalidade que se associa a esse modelo é a cognitivainstrumental, que é a racionalidade de um sujeito capaz de obter conhecimento sobre as contingências do ambiente e colocar este, em uso efetivo, na adaptação e manipulação desse ambiente. Habermas desloca a atenção para a dimensão comunicativa da ação, isto é, do que ocorre em termos de relações sociais, mediadas básica e fundamentalmente pela linguagem. É assim que a busca do entendimento se assenta na linguagem, e esta parece ser a razão pela qual Habermas desenvolve as idéias básicas de uma teoria da competência comunicativa.

Não é possível reduzir a ação comunicativa à fala ou ainda à conversa. A linguagem é um meio de entendimento, no qual os falantes integram os mundos objetivo, social e subjetivo em um sistema. E esse sistema que compartilham e do qual partem para a busca do entendimento e para se apresentarem uns aos outros com pretensões de validade que tanto podem ser reconhecidas quanto postas em questão. Assim, do ponto de vista pragmáti$\mathrm{co}$, a linguagem só será relevante quando posta a serviço do entendimento.

Face à sua natureza harmonizadora e seu vínculo essencial com o entendimento social, a ação comunicativa é o único caminho para o racionalismo e a única forma de ultrapassar as tendências conservadoras do pensamento, que anunciam um pretenso esgotamento do projeto modernista e a descolonizar o mundo da vida, submetido de todas as formas às normas jurídicas e econômico-administrativas do sistema, como Habermas tão bem descreve.

Teoria da Ação Comunicativa é a grande obra sistemática de Jürgen Habermas. As idéias ambiciosas nele contidas estão sendo atualmente discutidas por especialistas de diversos campos do conhecimento. Sua importância para a análise organizacional é inquestionável. Ainda são poucas as aplicações em textos e teses, mas parecem aumentar dia a dia as tentativas nesse sentido. Trata-se de um pensamento vigoroso, que precisa ser conhecido e discutido em nossos meios de ensino e pesquisa. $\square$ 